\title{
At and with the Sea: Le Corbusier's Path towards a "Desiring-Machine"
}

\author{
By Maria Joao Soares* \\ Clara Germana Goncalves ${ }^{\dagger}$
}

This paper aims to place Le Corbusier's thought and work in a contemporary realm with the aid of Gilles Deleuze and Félix Guattari's philosophy, using the poet and essayist Paul Valéry as an intermediary. From the sea to Paul Valéry, to Le Corbusier and to architecture. From the machine as a mechanism - so loved by Le Corbusier to the desiring-machine of Gilles Deleuze and Felix Guattari as a machinic instrument. From an immemorial past - the sea - to a recent past - Valéry and Le Corbusier; and to a future - an architecture that works the materials of expression of the body, to a duplicate of that very body; a body inhabited by itself in itself. As a desiring-machine. As an apparatus. The apparatus as a reflection of Le Corbusier's longing for the Mediterranean Sea - and for the objet à reaction poétique. We can assume this object (à reaction poétique) to be a conductor of the immanent possibility of a non-preconceived form, as the conductor of an "open" thing that thrives, as an intrastructure, for the machinic. Something that goes beyond the traditional antinomies of modernism. Again, something for a future: a living-in-a-living-body.

\section{At and with the Sea}

Free man, you'll always love the sea - for this, That it's a mirror, where you see your soul In its eternal waves that chafe and roll; Nor is your soul less bitter an abyss.

Charles Baudelaire, "Man and Sea", Les fleurs du mal [translated by Roy Campbell $]^{1}$

In his book Le Corbusier: The Architect on the Beach (2011), Nicolas Maak writes: "'In one of the most beautiful passages that Valéry wrote', said Walter Benjamin, 'the sea and mathematics enter into a captivating union'. This combination of rules with chance forms that can only be found, not invented, would later become a central philosophical motif in Le Corbusier's writings." 2

Paul Valéry (1871-1945) holds in his hands a large spiralling seashell; with his head down, he seems to be looking at the object carefully, asking

\footnotetext{
* Research Fellow/Associate Professor, CITAD/Lusiada University, Portugal.

$\dagger$ Research Fellow/Associate Professor/Invited Assistant Professor, CITAD, Lusiada University/ ISMAT,Portimao/University of Lisbon, Portugal.

1. Charles Baudelaire, As flores do mal (Lisboa: Assírio e Alvim, 1992).

2. Niklas Maak, Le Corbusier: the Architect on the Beach (Munich: Hirmer, 2011), 125.
} 
himself questions. There is a photograph of this. The poet and essayist, repeatedly wrote about the sea and objects he would find on beaches. To be found in his notebooks, accompanied by sketches of sea shells and seaside scenes.

In a letter to the editor of the journal Le Petit Méridional, Valéry wrote that when he was young he had found a strange object on a beach. "I was fifteen or sixteen', he wrote, 'when, on the seashore not far from Maguelonne, I found a shell or a piece of bone that had been tossed about and smoothed by the sea." "3 This object was to become one of the driving forces behind one of the most noteworthy passages in Eupalinos ou l'Architecte (1921).

Eupalinos: two men no longer of the physical plane - Socrates, the philosopher, and his disciple and friend Phaedra - discuss "the act of constructing". The two men are wandering about Hades, shadows without bodies. They talk about architecture. Socrates relates an experience with a strange object he found on a beach in his youth. A strange object that marked his life: the decision to be a philosopher or an architect. The origins of thought divided between constructing and knowing.

Let us look for a moment at Valéry and Eupalinos. Valéry begins by introducing Socrates as an architect manqué, a man who circumstances prevented from training as an architect (in the dialogue it is Socrates "himself" who says this). But where does this secret "architect" come from? Socrates says: "A je ne sais, quelle intention profonde de construire qui inquiète sourdement ma pensée.",

An object at the origins... an object of "réfléxions infinies" that is at the origin of thought. But not of thought as an integral thing; thought that is itself torn between construction and knowledge. Phaedra exclaims: "Merveilleux objet!" Valéry, through the mouthpiece of Socrates, speaks of a simple object. Something that is apparently nothing. As insignificant - or significant - as the objects we might find on the ground on a daily walk. Just like Socrates' walk by the sea, on an endless beach, as related by himself to Phaedra in an imagined dialogue.

A young Socrates "struggling" with the sinuous line - continuous and discontinuous - of the sea on the sand. ${ }^{7}$ It is with his soul abandoned " $a$ cette musique si puissante et si fine", - the sound of the waves - that Socrates finds the object. He finds something he was not looking for, in a particular spot where what the sea rejects and the earth cannot retain meet. It is in this context determined by the elements that Socrates finds something given up by the sea and makes him first unsure if it belongs to the sea or the land. Something white, "de la plus pure blancheur", , polished, hard, but soft and light. The
3. Ibid, 118.
4. Paul Valéry, Eupalinos ou l'Architecte (Paris: Editions Gallimard, 1995), 71.
5. Ibid, 73.
6. Ibid.
7. “Toutes choses, autour de moi, étaient simples et pures: le ciel, le sable, l'eau." Ibdi, 74.
8. Ibid, 75.
9. Ibid, 77. 
thing stands out against the wet sand, which is dark, shining in all its whiteness in the sun.

Socrates picks up this uniquely formed object, blows sand off it; his thoughts become occupied by it:

Qui t'a faite? Pensai-je. Tu ne ressembles à rien, et pourtant tu n'es pas informe. Est-tu le jeu de la nature, ô privée de nom, et arrivée à moi, de par les dieux, au milieu des immondices que la mer a répudiées cette nuit ${ }^{10}$

It is not the immenseness of the object that Socrates loses himself in; it is only the size of his fist. He loses himself in the material, its constituent matter. In "la même matière que sa forme: matière à doutes". ${ }^{11}$ Material for doubt, material of doubt. And these doubts as to the matter ${ }^{12}$ lead to doubts as to its maker:

Ou bien, n'était-ce pas l'œuvre d'un corps vivant, qui, sans le savoir, travaille de sa propre substance, et se forme aveuglément ses organes et ses armures, sa coque, ses os, ses défenses; faisant participer sa nourriture, puisée autour de lui, à la construction mystérieuse qui lui assure quelque durée? ${ }^{13}$

A machinic ${ }^{14}$ object enclosed in the folds by the actions of external moulding forces?

An object, with a divine "aspect" with its fleeting form belonging to the family of the countless forms produced by the sea - the eternal work of the waves.

Looking at and considering all of the aspects of the open object, that was in his hands and time. Time leads Socrates to ask himself, incessantly, without finding any reply: "Que cet objet singulier fût l'œuvre de la vie, ou celle de l'art, ou bien celle du temps et un jeu de la nature, je ne pouvais le distinguer... Alors je l'ai tout à coup rejeté à la mer." "15 Throwing the object back into the sea... Does that action contradict the fascination inherent to the object? Socrates answers: "L'esprit ne rejette pas si facilement une énigme." enigma as a challenge.

10. Ibid, 78 .

11. Ibid.

12. "C'était peut-être un ossement de poisson bizarrement usé par le frottement du sable fin sous les eaux? Ou de l'ivoire taillé pour je ne sais quel usage, par un artisan d'au-delà les mers? Qui sait?... Divinité, peut-être, périe avec le même vaisseau qu'elle était faite pour préserver de sa perte?" Ibid.

13. Ibid, 79.

14. English translation of the original french term machinique. Machinique is a concept by Deleuze and Guattari used to, for exemple, illustrate the desiring-machine's [machine désirante] working system whitch not having a purpose deviates from the mechanic. It is beyond mechanic: it is machinic.

15. Ibid, 81 .

16. Ibid. 
Nicolas Maak writes:

The converse approach - which in Valéry's intellectual experiment would have made an architect of Socrates - would have led Socrates to realise that the world can be reinvented outside the existing categories, that it can be rethought. Anyone who does not register the classificatory openness of the found object as a threat to their entrenched view of the world, but who is encouraged and elated by the challenge it represents, will focus not on knowing, on cognition - which is understood here as re-cognition - but on the possibility of perceiving new, previously inconceivable forms. ${ }^{17}$

The philosopher, as Valéry's mouthpiece, stresses his youth when he found this unnamed and unknown object - "Je t'ai dit et redit que j'avais dixhuit ans!" ${ }^{18}$ Socrates uses youth to explain a still immature, albeit open and accessible, way of thinking. Le Corbusier, who read Eupalinos when he was writing Vers une architecture (1923), highlighted this passage in his copy of the book. ${ }^{19}$

And one understands why:

Look at the surface of water... Look at the blue sky, filled with all the good works that men will have created.... In the final account, the dialogue is reduced to a man alone, face to face with himself, the struggle of Jacob with the Angel, within man himself! $!^{20}$

It is difficult to not associate Le Corbusier with Valéry's description. One could even substitute the figure of an imaginary Socrates with Le Corbusier (would Socrates, in this dialogue, not have become an architect if only he hadn't succumbed to doubts?).

Le Corbusier's connection to the writings of Valéry is well known. In addition to Eupalinos - the chapter entitled "Architecture, pure création de l'esprit" from Vers une Architecture, seems to reveal the significant influence of Valéry - he also read, and notated, other books by Valéry. "In the late 1940s, while developing his Modulor theory of design and writing Le Poème de l'angle droit, he consulted Valéry's 'Une Vue de Descartes' ('A View of Descartes'), 'Mémoires d'un poème' ('Memoirs of a Poem'), Pieces sur l'art (Pieces on Art) and 'L'Homme et la coquille' ('Man and the Seashell')."21

17. Maak, Le Corbusier: the Architect on the Beach, 123.

18. Valéry, Eupalinos ou l'Architecte, 86.

19. Maak, Le Corbusier: the Architect on the Beach, 119.

20. Le Corbusier, "Mise au point," in Le Corbusier: The Final Testament of Père Corbu, by Ivanka Žaknić (New Haven, CT: Yale University Press, 1997), 85.

21. Maak, Le Corbusier: the Architect on the Beach, 133. 
Le Corbusier, Paul Valéry and the Sea

Le Corbusier not only owned copies of Valéry's books, but also made prolific notes in them on the margins. The marks of an avid reader. But more than this, they are the marks of a builder; he, too, of written and described universes. Maak further writes: "Le Corbusier identified with Valéry. When the writer states that he has given up poetry but harbours it within as a secret and a nucleus, Le Corbusier underlined 'secret' and 'nucleus' and adds 'Magnificent!',"22 Bravo!

It is known that the architect sent a copy of Vers une Architecture to Valéry, and the latter responded with a letter thanking him. Moreover, it seems possible that the two may actutally have met. ${ }^{23}$

Towards the end of his life Le Corbusier himself states:

One day Paul Valéry told me... I work like an angel.... He wrote it to me or he told me... I don't know how the situation came about, but anyway I knew Paul Valéry - he said to me, "You write wonderfully"; while everybody else was telling me, "You have no style; to have a style, you have to have a twisted style.", 24

It was probably Auguste Perret, a friend of Valéry's, with whom Le Corbusier - still using the name Charles Édouard Jeanneret -, worked in Paris in 1908, who brought the poet to Le Corbusier's attention. In October 1923 Valéry and Perret were responsible for the publication of the magazine L'Architecture vivante. Some historians of architecture even argue that the conversations between Valéry and Perret influenced the writing of Eupalinos. Maak believes the reverse is true: "Valéry's theories influenced Perret's few remarks on architecture." 25

In 1926 Le Corbusier made a direct reference to Eupalinos in his Almanach d'architecture modern (1925): “'In a book with the title Eupalinos, or The Architect Paul Valéry, as a poet, succeeded in saying things about architecture that a professional would never be able to formulate, because [the professional's] lyre is not attuned to that tone: he has felt and expressed admirably many profound and rare things that an architect senses when he creates." 26

Let us return to Socrates and the curious object he plucked from the seafoam. Let us go back to Le Corbusier's very own copy of Valéry's book; to the notes on the page margins. Le Corbusier wrote: "I have found one of these things",27. Le Corbusier and Valéry's objet ambigu. It would appear that the poet, through his work, may be responsible, or at least may have provided the

22. Ibid, 135.

23. Ibid, 128.

24. Le Corbusier, "Mise au point," 117.

25. Maak, Le Corbusier: the Architect on the Beach, 128.

26. Maak, 129.

27. Maak, 130. 
legitimacy for - the genesis of a particular process in the context of architecture: Le Corbusier, himself a collector of unlikely objects surrendered by the sea. Shortly after reading Eupalinos, objets ambigus were included in the Pavillon de l'esprit nouveau (1925). A literary model revised in an architectural context? More than that. For Valéry the objet ambigu went beyond writing. And for Le Corbusier the strange objects found on the beach entered the inner depths of his work. The deepest depths. We are now in the realm of the objet à réaction poétique that fosters the ineffable.

Le Corbusier's always hidden interest in photography presented, particularly between 1936 and 1938, objects of various types - mostly produced by nature itself: bones, rocks, sea shells, flotsam. All of which were shown in detail and abstraction. From 1928 onwards they made their way into his paintings. Tim Benton writes:

These photographs can roughly be divided into images of visual stimulation for his paintings and natural forms that seemed to him to have more symbolic role, standing for the great ordering principles of nature. Many of the former are photographic equivalents of the little sketches he made in his notebooks and sketchbooks as visual reminders and stimuli for his painting. There are hundreds of these.

$[\ldots]$. He described these "objects à réaction poétique" $[\ldots] .{ }^{28}$

Objets à réaction poétique as a counterpoint - or an approximation - to Valéry's objets ambigus. Objects that emerge on the boundary between being and not being and offer inherent possibilities of being rebuilt. As Maak states, "Le Corbusier refers to his objects as 'speaking' and 'evocative companions'. Valéry's beach object is 'polished and hard and smooth and light', Le Corbusier's "smooth as porcelain'., 29 To both, the objects are "testaments", both seek to understand how their forms came about - intent and chance. Both seek an espistemical understanding, according to Maak: "constructing and knowing". "Tim Benton continues:

Le Corbusier was principally interested in the sensual pleasure to be derived from objects, but he was also developing in these years a personal mythology based on the cosmic forces of nature. We can trace the origins of these ideas to the early 1920s, when he began collecting seashells and other objects, which he saw as demonstrating a link between the geometry of natural forms and the universal laws of harmony. In 1923, he wrote to Hendrik Theodor Wijdeveld, the editor of the luxurious Amsterdam-based magazine Wendingen, praising him for the magnificent issue they had just produced featuring photographs and X-rays of seashells. Le Corbusier claimed that he had been collecting shells for some time, but that he was

28. Tim Benton, LC Foto: Le Corbusier Secret Photographer (Zurich: Lars Müller, 2013), 306.

29. Maak, 121.

30. Ibid. 
particularly struck by the X-Ray photographs, because they showed the shells' hidden structure, formed along the geometry of the golden section. $^{31}$

The avid Le Corbusier. The enthusiast. On a beach, it was not only occasional objects that attracted his attention, there was - and is - also the sea. The architect photographed the sand. He photographed it trying to understand how it moved in reaction to the forces of the sea, the wind - seeming to look for a cinematic effect. Moulded sand. "This is both a highly architectural way of looking - searching for cause and effect - and also a reflection on nature and its cosmic system, at a tiny scale." 32 Where does the man begin and end and where does the architect begin?

\section{Towards a "Machinic" Concept}

Paul Valéry writes:

[...], he [man] is particularly fascinated by those which, by their form or properties, lead him to reflect on his own powers or tendencies. He is amazed to find objects which, though it is inconceivable to him that they should have been made, he can compare to those he is able to make. In such objects he seems to recognize his own familiar modes of thought, his own types of conscious action: his incorrigible "causality" and "finality"; his geometry; his ingenuity; his need for order and his bursts of inventiveness." 33

Here "man" could be understood as Le Corbusier. A very specific man comes to mind. Is he not Le Corbusier? Could he not be the architect? We can imagine Le Corbusier saying, about this paragraph: Wonderful! Magnificent! as shown by his notes in the books by Valéry. There is almost a sense of indiscernibility between the architect - as a man - and the poet.

The shell which I hold and turn between my fingers, and which offers me a combined development of the simple themes of the helix and the spiral, involves me in a degree of astonishment and concentration that leads where it may: to superficial remarks of reckless "theories."... And my mind vaguely anticipates the entire innate treasure of responses that rise within me in the presence of a thing that arrests and questions me... ${ }^{34}$

Imagine Le Corbusier standing with his feet in the seafoam - his body upright. Imagine Le Corbusier's hands. The hands that are Le Corbusier -

31. Benton, LC Foto: Le Corbusier Secret Photographer, 309.

32. Ibid, 313.

33. Paul Valéry, Sea Shells (Boston, MA: Beacon Press, 1998), 13-14.

34. Ibid, 24. 
more than his face, as André Wogenscky ${ }^{35}$ writes. Hands open. Ink. Charcoal. And an objet à reaction poétique in his hands:

\section{Tenderness! \\ Seashell the Sea in us has never \\ Ceased to wash its wrecks of \\ laughing harmony upon the shore. \\ Hand kneading hand caressing \\ Hand brushing. The hand and the \\ Seashell love each other. ${ }^{36}$}

In Homme et la Coquille [Sea Shells] (1936) Valéry delights himself and the reader with detailed descriptions of the shells he turns in his hands: "[...] in the end the tube suddenly broadens, breaks, curls back, and overflows into uneven lips, often bordered, waved, or flitted, which part as though made of flesh, disclosing in a fold of the softest mother-of-pearl the smoothly inclined starting point of an internal whorl that recedes into darkness." 37

But something else happens in this little book. Something beyond the afore-mentioned descriptions. The reader enters into a particular realm. The realm of the animal-thing and how it is made. Being and being made. In 1998, in a foreword to Valéry's Sea Shells, Mary Oliver compares the shells described by the essayist to an apparatus - an apparatus that mediates Valéry's reflection on form and origins, turning it into a manifesto, an idea. ${ }^{38}$ Thus, Oliver makes the connection between these strange objects of nature, the sea shells, and creation outside of nature. Production of self, for self and in self.

Valéry explains how the sea shell emanates from the mollusk. And he stresses the definition of emanation as that which, for him, comes closest to reality. For the correct meaning is: to exude, to project. "A grotto emanates stalactites; a mollusk emanates its shell. As to the elementary process of this emanation scientists tell us many things that they have seen under the microscope." 39

The mollusk emanates, exudes, its own home. The home results from the living being, as is a living part. The mollusk machines itself. Apparatus?

The mollusk emanates from itself, from its core, from its guts, its own envelope of protection and shelter. Valéry writes:

I have read that the animal we are examining draws food containing calcium salts from its environment, and that the calcium is extracted and digested by the liver, whence or passes into the blood stream. This is the raw material for the mineral part of the shell - it will feed the activity of a

35. Andre Wogenscky, Les mains de Le Corbusier (Paris: Éditions du Moniteur, 2006), 12.

36. Le Cobusier, Le poème de L'angle droit, n.p.

37. Valéry, Sea Shells, 29-30.

38. Mary Oliver, "Foreward," in Sea Shells, by Paul Valéry (Boston, MA: Beacon Press, 1995), 7.

39. Valéry, Sea Shells, 65-66. 
strange organ specialized in the craft of secreting the elements of the solid body to be constructed and of putting them in place. ${ }^{40}$

On the outside, its mucus cells and the calcite forms - in growth - the hard and more aggressive textures - needed for the outer world; on the inside, the reverse, the surface is soft and polished, nacreous, protecting the body that takes refuge in its folds. Layers in growth; folds in progression. As Valéry writes: "[t]here is nothing too precious or delicate for the medications of a life so much of which is spent at home, [...].",41

The body coming out of itself and remaining a body in itself. Double belonging. Maak describes the outer shell as the "sediment of life". ${ }^{4}$

Valéry believes that the shells are not the product of a machine, of intention, or of chance. "[T] he making of the shell is lived, [...]." ${ }^{\text {"43 }}$ Another type of machine. A living machine. In a letter to Le Corbusier Valéry writes: "II have often dreamt of a house in which the structure and all the qualities are those of a modern machine." 44 What kind of dreams are these? Dreams of houses machined by the body? "Nothing we know of our own actions enables us to imagine what it may be that so gracefully modulates these surfaces, element by element, row by row, without other tools than those contained in the things that is being fashioned."

The core of the body - like the Modulor's body - is coming out. It is its machine... Now the machine belongs to the realm of the visible. Here I am. I am the body. I am the supreme machine. Let the machinic out of me... Let me produce something with myself, with my own fibre. Let me extract what I am, become something outside of my body: and here I am, I live outside of myself, being myself.

\section{Desiring-Machines}

World as a Machine

For Valéry, the work of art is a "machine to impress the public; to arouse emotions and their corresponding images". This definition of the work of art as an activating "machine" throws new light on Le Corbusier's frequently misunderstood notion of the modern house as a "machine for living in". In terms of Valéry's theory, this house would be an apparatus with fluid open spaces stimulating the occupants to discover forms of daily life different from those of convention. The house is thus a "poetic object" in the sense that it

40. Ibid, 79-83.

41. Ibid, 80 .

42. Maak, Le Corbusier: the Architect on the Beach, 142.

43. Valéry, Sea Shells, 77.

44. A Valéry's letter to Le Corbusier acknowledging the reception of a copy of Vers une Architecture. Maak, Le Corbusier: the Architect on the Beach, 128.

45. Valéry, Sea Shells, 91. 
generates new forms of life and adopts for its user the role that the "object à réaction poétique" had possessed for its architect at the outset of the design process. $^{46}$

Paul Valéry speaks of art as a "machine to impress the public", but one can take this further - returning to the old notion of the machine à habiter - and establish a new vision for Le Corbusier's architecture as an apparatus that leads to Gilles Deleuze (1925-75) and Félix Guattari's (1930-92) “desiring-machine”.

In 1972 Deleuze and Guattari wrote:

Everywhere it is machines - real ones not figurative ones: machines driving other machines, machines being driven by other machines, with all the necessary couplings and connections. An organ-machine is plugged into and into an energy source machine: the one produces a flow that the other interrupts. The breast is a machine that produces milk, and the mouth a machine coupled to it. [...]. Hence we are all handymen: each with its little machines. For every organ-machine, an energy-machine: all the time, flows and interruptions. ${ }^{47}$

In 1923 Le Corbusier wrote: "A house is a machine for living in. Baths, sun, hot-water, cold-water, warmth at will, conservation of good, hygiene, beauty in the sense of good proportion. An armchair is a machine for sitting in and so on." 48

Deleuze and Guattari: everything is a machine! We know, in the early $20^{\text {th }}$ century, the machine was in the air du temps.

Le Corbusier:

One day I was in my student room at quai Saint-Michel, my student room on the seventh floor, by the attic window. Suddenly I hear a terrific noise, I run to the window, and I see an airplane go by. It was the Count de Lambert's airplane flying over Paris for the first time. That was a shock. [...]. And this was an event in the history of mankind. Aviation was born at that moment, and was proving its potential. ${ }^{49}$

Later, close to his death, he wrote that Pierre Jeanneret and Amédée Onzenfant spent some of their time dismantling and rebuilding their automobiles... "Anyways, all these tales of the beginning of automobiles in the lives of men, of their use." All these tales... But we know, through Le Corbusier himself, that these tales do not get lost in the machine for the

46. Maak, Le Corbusier: the Architect on the Beach, 127.

47. Gilles Deleuze and Felix Guattari, Anti-Oedipus (London: Bloomsbury, 2012), 11.

48. Le Corbusier, Towards a New Architecture (Mansfield, CT: Martino Publishing, 2014), 95.

49. Le Corbusier and Hugues Desalle, "The Final Year: A Transcription of Le Corbusier's Last Recorded Interview," in Le Corbusier: The Final Testament of Père Corbu, by Ivanka Žaknić (New Haven, CT: Yale University Press, 1997), 109.

50. Le Corbusier and Desalle, "The Final Year: A Transcription of Le Corbusier's Last Recorded Interview," 110. 
machine's sake. In other words, in the exclusively mechanical. "There is a moral sentiment in the feeling for mechanics." ${ }^{51}$ We have the Parthenon as a testament to this: "We may then affirm that the airplane mobilized invention, intelligence and daring: imagination and cold reason. It is the same spirit that built the Parthenon." ${ }^{, 52}$ Le Corbusier:

[...], the Parthenon appears to us as a living work, full of grand harmonies. [...]. The perfection in this case is so much outside the normal, that our apprehension of the Parthenon can only correspond nowadays with a very limited range of sensation, and, unexpectedly enough, with sensations of a mechanical kind; its correspondence is rather with those huge impressive machines with which we are familiar and which may be considered the most perfect results of our present-day activities, the only products of our civilization which have really "got there". 53

Le Corbusier goes on to assert that all the "plastic machinery", in relation to the Parthenon, is made of marble with the rigour we apply to a machine. $\mathrm{He}$ goes even further than that: "The impression is of naked polished steel."54 "The Parthenon is moving; [...]."

Desalle: So, you think, and you admit that the Parthenon is functional architecture.

Le Corbusier: No, no... it functions in that it moves you... that's it.

$[\ldots]$, the human presence in all the Greek works has stayed with me always. $^{56}$

Parthenon: machine à émouvoir.

In September 1936 (coincidentally, the year of publication of Valéry's Homme et la coquille) Le Corbusier took a series of self-portrait photographs his reflection in a mirror (Figure 1). His body is naked. A propos these selfportraits Tim Benton speaks of Le Corbusier's midlife crisis. ${ }^{57}$ But what do we see? We see a body clearly coming out of obscurity... Being extracted from the background. There is somewhat more lighting on the left side - just a little. There is no face. No face, arms raised - left armpit - holding the camera, which blends into the darkness. The focal point is the torso. The belly button is the centre of the body. Later also the centre of the body in the Modulor. The centre of the body is the machinic place! The self-portrait is focused on the naked body. Naked, without shame. Naked. The right leg is slightly bent. Behind the body, folds of fabric also emerge from the darkness. The

51. Le Corbusier, Towards a New Architecture, 127.

52. Ibid, 109.

53. Ibid, 144-145.

54. Ibid, 217.

55. Ibid, 164-165.

56. Le Corbusier and Desalle, "The Final Year: A Transcription of Le Corbusier's Last Recorded Interview," 117.

57. Benton, LC Foto: Le Corbusier Secret Photographer, 186-187. 
composition revisits ancient Greece... A self-portrait as a timeless sculpture. And there is also a smell of the sea - a hint of the Mediterranean. A selfportrait at the age of forty-nine, before the turning point, before the "sixty". Practically ten years later came the Modulor.

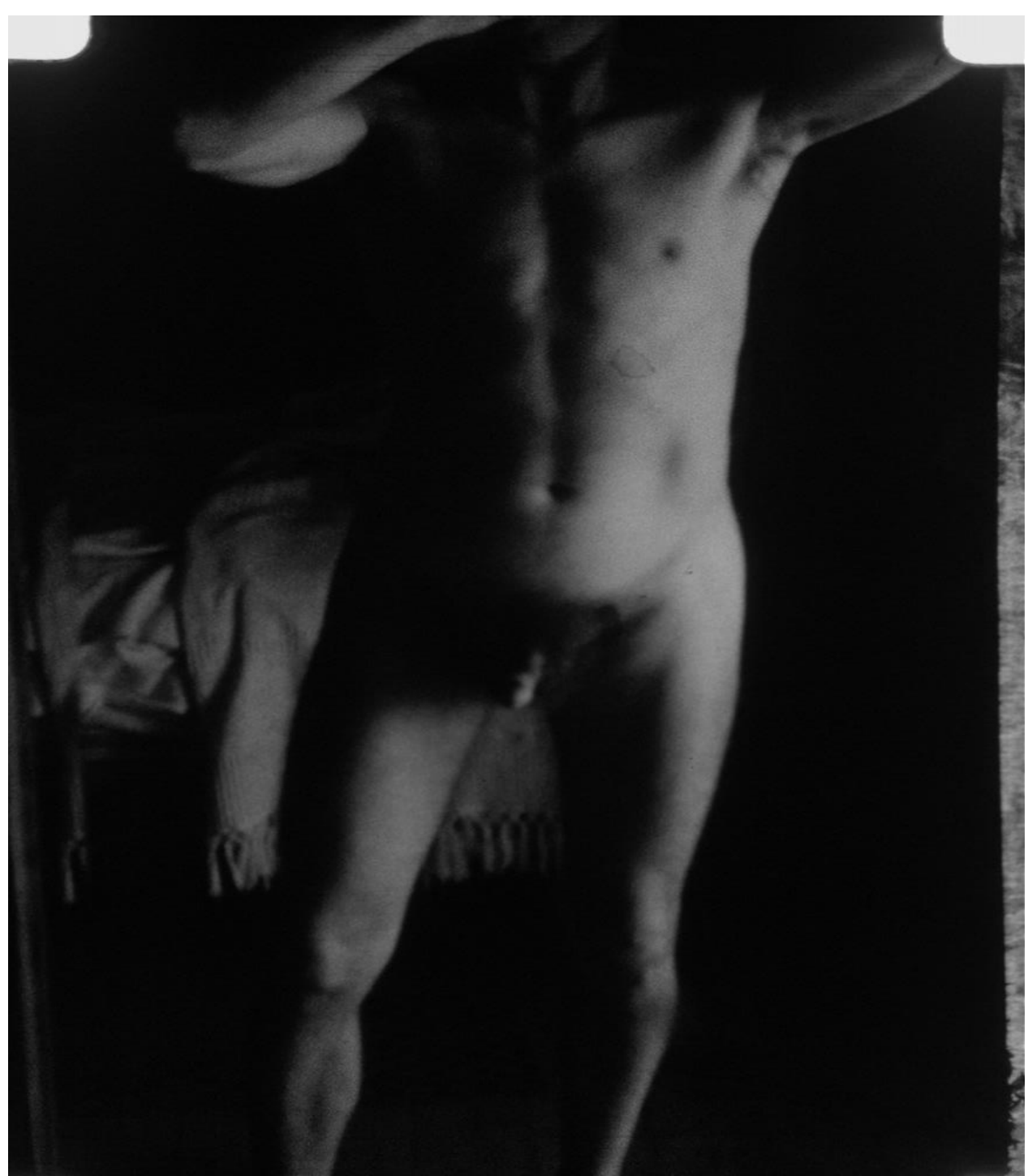

Figure 1. Le Corbusier's Self-portrait (1936)

Source: (C) FLC/ADAGP, Paris/OSDEETE, Athens 2016.

The anthropomorphic body is itself already a machine. It processes the associative flow. The mouth will cut speech, air, milk [food]. Likewise, it will afford the conditions of possibility of that material passage; it provides a set of thresholds and surfaces that enable the passage of matter, of stuff. The anthropomorphic body, then, is a armature, machinic system, and material 
flow. [...] The body is one site among many where the machine and the endless anorganic vitalism of surfaces and flows converge. ${ }^{58}$

Anthropomorphic body as a machinic system. Le Corbusier knitting with the machinic ideal. Is the figure of man in the Modulor system not a desiringmachine (Figure 2)? The centre of the body as a machinic thing!

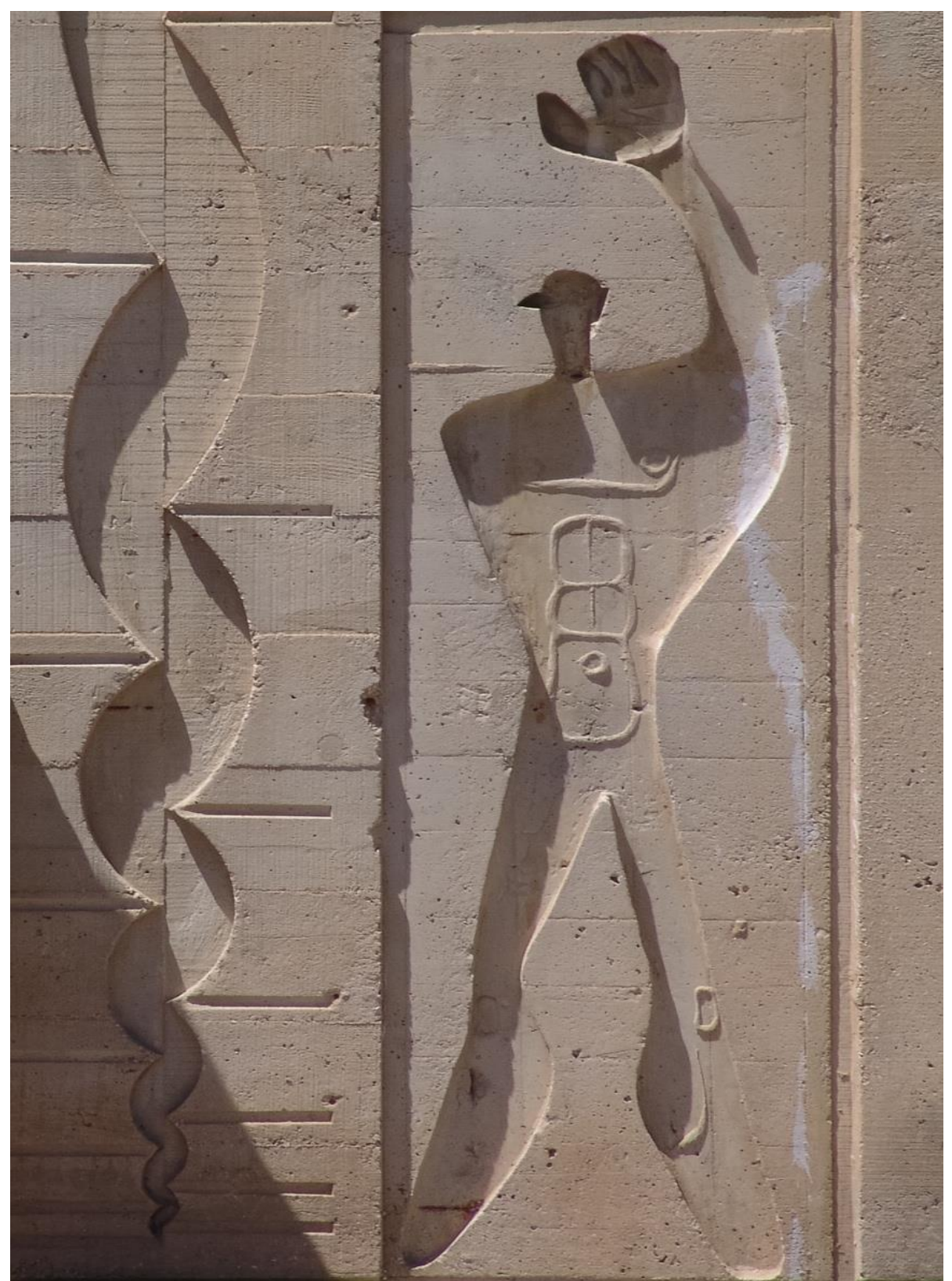

Figure 2. Man's Modulor at Unité d'habitation de Marseille (1945-52) Source: Maria João Soares, 2006.

58. Jaleh Mansoor, "Kurt Schwitters's Merzbau: The Desiring House," in Lotus International 123 (Milan: Editoriale Lotus, 2005): 57. 
Deleuze and Guattari:

[...], we make no distinction between man and nature: the human essence of nature and the natural essence of man become one within nature in the form of production or industry, just as they do within the life of man as a species. [...]. [The man] who is responsible for even the stars and animal life, and who ceaselessly plugs an organ-machine into an energy-machine, a tree into his body, a breast into his mouth, the sun into his asshole: the eternal custodian of the machines of the universe. ${ }^{59}$

What are these desiring-machines that are advanced by the philosophers? They are binary machines that function in accordance with a binary set of rules related to each other: "one machine is always coupled with another. [...] there is always a flow-producing machine, and another machine connected to it that interrupts or draws off part of this flow (breath - the mouth). [...]."60

José Gil argues that the concept - the desiring-machine - proceeds from a new conception of desire. That desire is defined as the "desire to compose", to combine, in other words, to "machine". ${ }^{61}$ Desiring-machines are not mechanical. They "machine" - are machinic - but their mechanisms are not of the world of mechanics. Nevertheless, one must reaffirm that they are literally machines, not metaphors. ${ }^{62}$ A "machine", in this sense, means a device for the production/halting of flows that functions according to the intensity of the flows and the planes it operates on. Desiring-machines can be connected infinitely, producing energy - which is neither physical nor psychic - that passes through the organ-machines. ${ }^{63}$

Was it not like this in the work, and life, of Le Corbusier? Architecturemachine, organs in the body. Production/stop/production; production of energy through organ-machines. Man-machine, with a bone in its pocket. Yvonne, his wife; mother; matter. Circulation - and non-circulation - of flows.

In 1925 Le Corbusier wrote L'art décoratif d'aujourd'hui. He wrote about the machine. About nature. In the book are photographs of factories, an ostrich, and - why not? - palaces, boats, planes, cars. Mademoiselle Mistinguett. Turbines. Salons. And also drawings. Minutely-detailed drawings of particular machines: their systems and organs. The human digestive system: mouth, salivary glands... The digestive system of a plant (cross-section): tentacles, mouth, oesophagus... A picture of Saturn ("un fait vrai"). ${ }^{64}$

59. Deleuze and Guattari, Anti-Oedipus, 14-15.

60. Ibid, 16.

61. Jose Gil, O imperceptível devir da imanência: sobre a filosofia de Deleuze, (Lisboa: Relógio D’Água, 2008), 169.

62. Deleuze and Guattari, Anti-Oedipus, 12.

63. Gil, O imperceptivel devir da imanência: sobre a filosofia de Deleuze, 171.

64. Le Corbusier, L'Art décoratif d'aujourd'hui (Paris: Flammarion, 1996), 183. 


\section{Body without Organs}

The question of artistic expression, when associated with desiringmachines, depends on a specific "figure" that is an inherent part of Deleuze and Guattari's philosophy - the body without organs. One can and must ask: what kind of body is that?

The body without organs [...]; it has nothing whatsoever to do with the body itself, or with an image of the body. It is the body without an image. This imageless, organless body, the non-productive, exists right there where it is produced, in the third stage of the binary-linear series. It is perpetually reinserted into the process of production. ${ }^{65}$

While not a body, nor an image of the body, the body without organs is still in some ways dependant on the body. In other words, emanation from the organic body, from the "own body", to build a body without organs. ${ }^{66}$

Once again, desire is a fundamental element in establishing the body without organs. When we desire we are in the body without organs, and when we desire it is that body that is desired: "a) desire desires to compose; b) desire desires immanence; and c) desire desires to flow." This will demand "a space, a territory so that desire can desire. Leading to a fourth proposition: d) it is necessary to build the space or the plane in/on which desire circulates and unfolds in accordance with its own strength." 67 That plane is the body without organs. Why body without organs? Gil argues that Deleuze takes the idea from Antonin Artaud and his Pour en finir avec le jugement de Dieu, defining two conditions for the body without organs: "it is not against the organs, but against the organism; it is a surface whose intensity $=0$, but is traversed by stronger intensities." Why is the body without organs against the organism? "The organism requires an organisation of the organs that creates an obstacle to intensification of the free energy. For this reason, in order to build the $\mathrm{BwO}$ [body without organs], the organism has to be dis-organ-ised." 68

Deleuze and Guattari:

The $\mathrm{BwO}$ [body-without-organs] causes intensities to pass; it produces and distributes them in a spatium that is itself intensive, lacking extension. It is not space, nor is it in space; it is matter that occupies space to a given degree - to the degree corresponding to do in intensities produced. It is nonstratified, unformed, intense matter, the matrix of intensity, intensity = 0 ; but there is nothing negative about that zero, there are no negative or

65. Deleuze and Guattari, Anti-Oedipus, 19.

66. Gil, O imperceptivel devir da imanência: sobre a filosofia de Deleuze, 185.

67. Ibid, 183.

68. Ibid, 184. 
opposite intensities. Matter equals energy. Production of the real as an intensive magnitude starting at zero. ${ }^{69}$

According to Deleuze and Guattari's philosophy, the body without organs offers the possibility of becoming-creation. In order to speak comprehensively on becoming-creation, one must understand that this whole operation depends on the plane of consistency and immanence that results from this emergence, from deep inside, to the surface of the body, the body without organs. "It is all the desire that is invested in it: above all, the tension between the nonproductive, sterile body that breaks down and halts the desiring-machines and a miraculed and miraculous body that attracts the machines of desire and constantly sets them in operation again". ${ }^{70}$ The breaking down of the desiringmachines is a necessity in the whole operation. The connecting syntheses need the breakdown in order to function even better. That is the role of the nonproductive body without organs ${ }^{71}$. To break down in order to improve production. The body without organs doubles down on the production instances, transforming repulsion into attraction. "In this doubling down, the body without organs communicates to the machines its (unproductive) movement and the machines inscribe themselves on its surface."

Is this not the error and perfect imperfection as a means of sublimation?

José Gil further argues:

The body without organs is the plane on which the various meta-stable states induce becoming-creations. Each state becomes another, becomes woman, becomes animal, becomes colour (painting), becomes sound (music). Hence the importance that the body without organs assumes in Deleuze's aesthetics. ${ }^{73}$

We are coming up to the surface of the body without organs, coming from the depth of the insides of the bodies, as Gil states, creating a consistent intensive plane of immanence ${ }^{74}$. We desire. And desire "creates compositions; and that movement opens up to new compositions, because composing means mediating, combining, connecting in order to flow better." 75 The body without organs is a question of worked, transformed matter - becoming-creation. As José Gil further argues: “ [...] - the writer's BwO [body without organs] is not made up of words, but of "writing', the result of his work on words.",76

"There is no point in wondering about the utility or non-utility, about the possibility or impossibility of such desiring-machines. Impossibility (and then

69. Gilles Deleuze and Felix Guattari, A Thousand Plateaus (London: Bloomsbury, 2015), 178.

70. Gil, O imperceptível devir da imanência: sobre a filosofia de Deleuze, 163.

71. Ibid, 171.

72. Ibid, 174.

73. Ibid, 177.

74. Ibid, 181.

75. Gil, 182.

76. Gil, 184. 
only rarely) and inutility (and then only rarely) are revealed solely by autonomous artistic representation."77

\section{Living-in-a-Living-Object}

“1950-1955. Liberté : Ronchamp. Architecture totalement libre.,"78

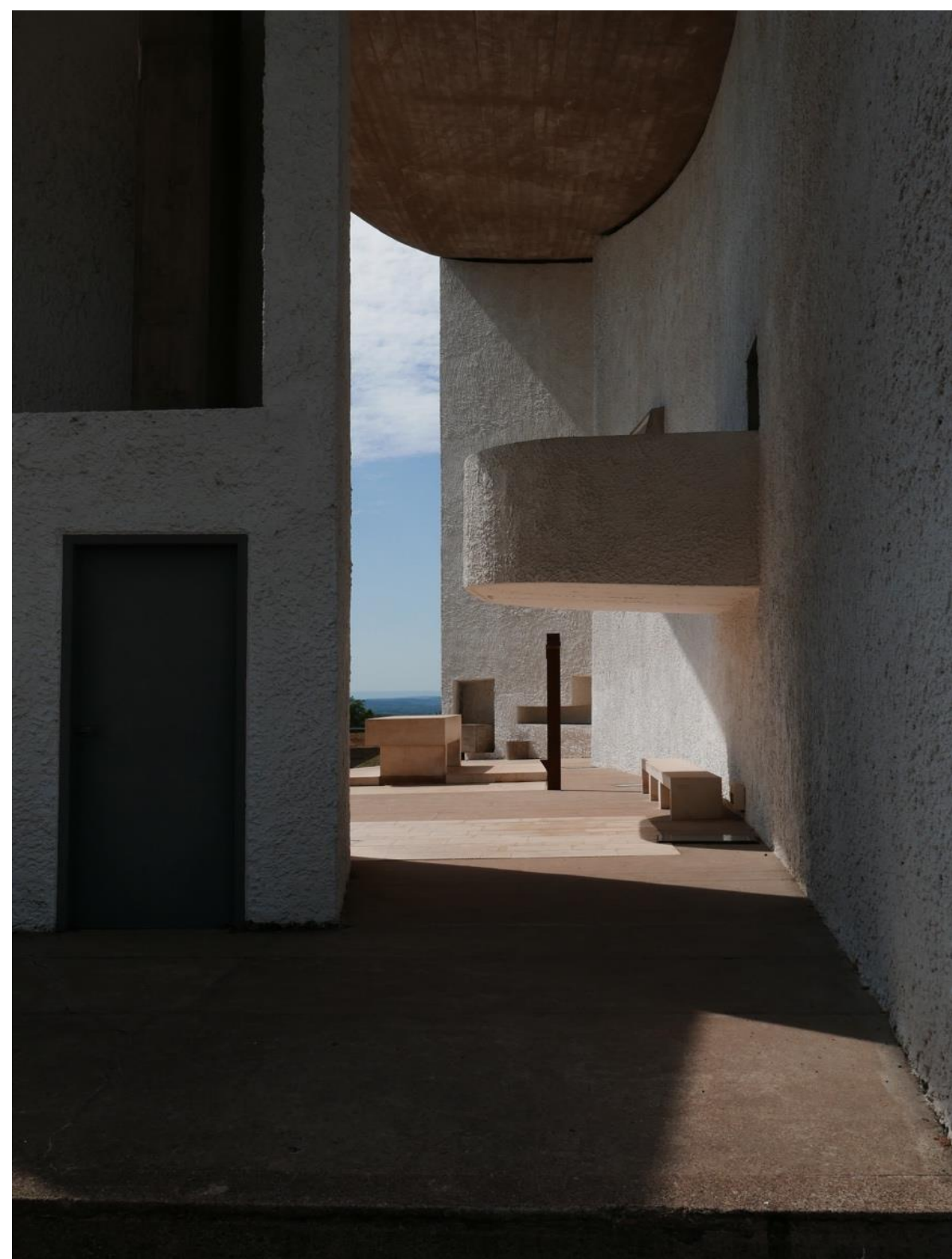

Figure 3. Chapelle Notre Dame du Haut, Ronchamp

Source: Maria João Soares, 2015.

77. Gilles Deleuze and Felix Guattari, "Balance-Program for Desiring Machines," in Lotus International 123 (Milan: Editoriale Lotus, 2005): 62.

78. Le Corbusier and Jean Petit, Textes et dessins pour Ronchamp (Genève: Association œuvre de Notre-Dame-du-Haut, 1990). 
“In 'Mémoires' he [Valéry] describes his decision to take up poetry again as returning 'invincibly, but by... small degrees, to a state of mind one thought had vanished forever'. Next to this Le Corbusier notes 'At sixty'. This must refer not to Valéry, who was only forty-six when he returned to poetry, but to Le Corbusier himself, who was sixty when he began to work on Le Poème de l'angle droit in 1947.",79

"At sixty". We reference that age once more, as a pivotal point. In a life. In a life's work. Le Corbusier seems to have waited for this age to finally become free. Liberté. The late 1940s and the 1950s were to be come a paradigmatic period in this at least seeming liberty. Le Corbusier wrote this in reference to Ronchamp (Figure 3), but it is clear both in his written works and in his built work. In the last 15 years of his life he became a man who wore his shirts open, swimming trunks pulled high up his legs. He was a naked man underneath a tree, his hands were marked by ink and charcoal. Open-handed.

If a writer's body without organs is made of writing (and not words), what does the body without organs of an architect consist of? Oblivious to the philosophical undertakings after his death, in the last decade and a half of his life, Le Corbusier established a machinic production. He dragged the material, working it and transforming it, up from the depths of the bodies to the plane of immanence, the plane where the becoming-connections are induced.

Our hero - oblivious to the passage from the machine as a mechanism to the machine as a desiring-machine, and therefore machinic - took to the wet sands of the beach, walking in Valéry's footsteps. One can imagine the scene. In a perhaps slow movement he picked up an object. An objet à reaction poetique. He found it on Long Island. He writes:

"On the drafting table lies a crab's Shell that I picked up on Long Island near New York in 1946. It becomes the roof of the Chapel [Ronchamp]: two connected concret skins six centimeters thick, and $2.26 \mathrm{~m}$ apart. The shell will lie on walls made of the salvaged stones...

The shell has been put on walls which are absurdly but practically thick. Inside them however are reinforced concrete columns. The shell will rest on these columns but it will not touch the wall. A horizontal crack of light $10 \mathrm{~cm}$ wide will amaze... ${ }^{80}$ (Figure 4 )

79. Maak, Le Corbusier: the Architect on the Beach, 135.

80. Text written in 1964, published by Jean Petit in 1965 after Le Corbusier's death. Le Corbusier and Petit, Textes et dessins pour Ronchamp. 


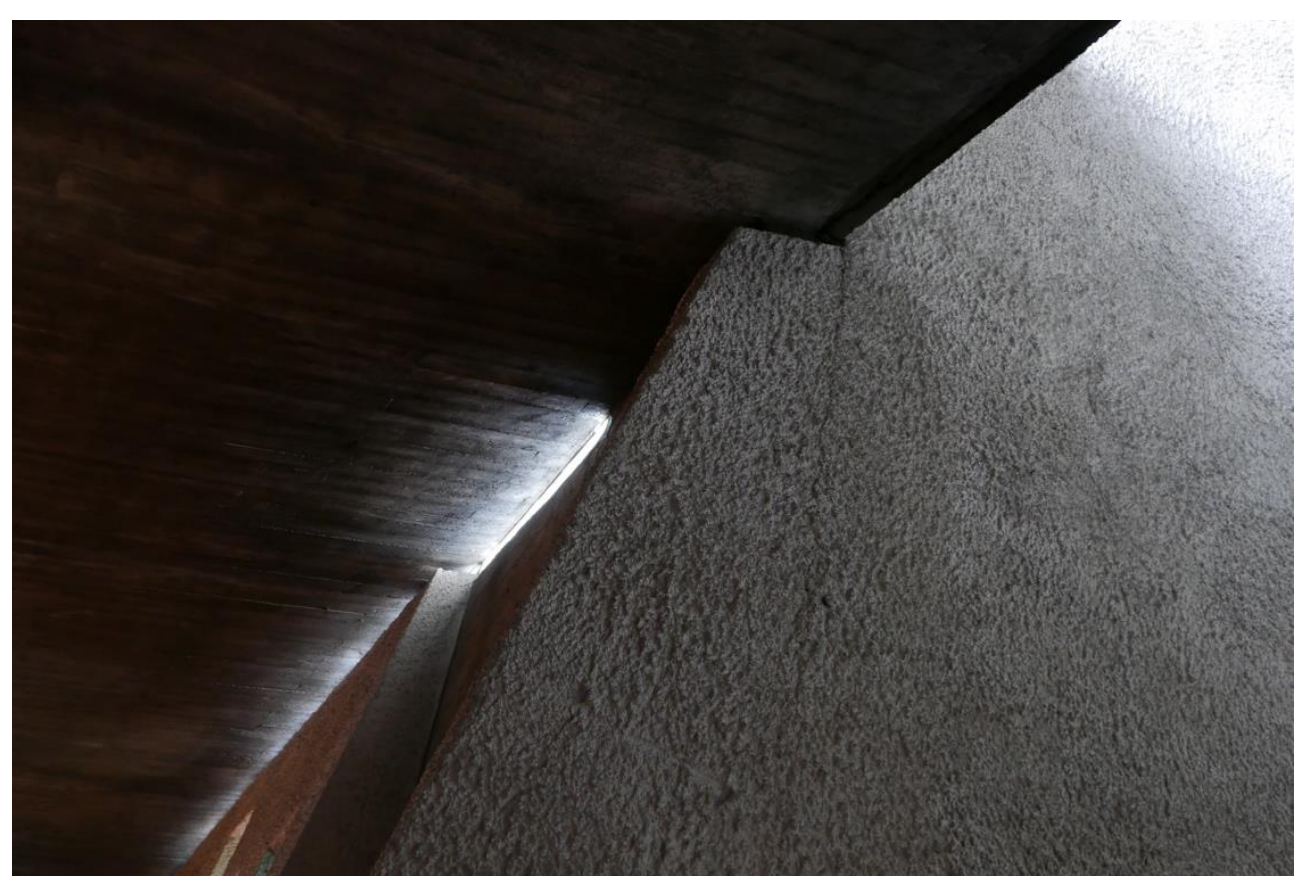

Figure 4. Chapelle Notre Dame du Haut

Source: Maria João Soares, 2015.

So Le Corbusier's find seems to lead him to the creative act. Reconstruction as a process of verification of certain facts - even if rooted in poetics. Morphogenesis? An architectural object does not have to be the opposite of natural forms, but likewise, it does not have to imitate the latter, in a very basic process. An architectural object can be approached via its structures - structures that manage and mediate nature - bringing it closer to the thing that is without time, without period.

Like Le Corbusier, Valéry's architect, Eupalinos, seeks to access the user's emotions through the use of mathematical proportion. That proportion should function as a fuse for emotion and vibration of the "soul": a kind of tremor of the soul of the user without knowledge of the cause.

Le Corbusier writes:

The "Poem of the Right Angle" was drawn, written and calligraphied between 1947 and 1953, during my various voyages, in the solitude of the airplane or of hotel rooms. In the poem, marked "B2: The Mind", deals with the Modulor. In order to validate it, like all the other subjects of the poem, the exercise had to be constructed in a valid architectural order. ${ }^{81}$

Here one could also add these words by the architect: "The fraction of the inch comes to play. The curve of the echinus is as rational as that of a large shell." ${ }^{82}$

81. Le Corbusier, Modulor 2 (Basel: Birkhäuser, 2004), 156.

82. Le Corbusier, Towards a New Architecture, 214. 
Let us return to the cinematic photographs of beaches. To the line between the natural thing and the manufactured thing; inert thing and living thing. The line of immanence where the matter of doubt of Valéry's objet ambigu and Le Corbusier's collected objects resides (think of the table in his Cabanon - a horizontal plane as an emotive display element for found objects and seashells). "To construct the $\mathrm{BwO}$ [body without organs] one has to connect the artist to the material of expression so that the intensities circulate from one to the other, blend, go into osmosis [...]." ${ }^{\text {83 }}$ Le Corbusier connected to the materials of expression. In osmosis.

Objets à réaction poétique are objects of the desire - even in the sense of Deleuze and Guattari's philosophy. Dismembered parts that long for connections and disconnections. The written conjunction of the Poème de l'angle droit (1955) with Le Modulor (1950), was to offer new connections andnew cuts, accordingly, elevating the architectural work to new experiences. We know that behind written creation and architectural creation, painting, sculpture they are always there; always as an absolute support. The Modulor measuring system, which could have been reductive in his work, ends up confirming his liberation.

With the Modulor, Le Corbusier elevates the status of the body as an anthropomorphic machine. The body as an armature, machinic system and with material flow. With his Convent of Saint-Marie de La Tourette (1953-60) and the anti-structural compositional relationships it establishes, Le Corbusier opened up a path for the machinic to enter the realm of architecture. The Convent is a set of organs without the body encasing them: a centrifugal force launches the organs into the space without releasing them. Architecture as an exposed organism, machinic system, and part-object. A "desiring-machine", showing of its errors and perfect imperfections as a means of sublimation. A non-unity as a whole.

1950-1955, Ronchamp: Chapel of Notre Dame du Haut

Le Corbusier builds his body without organs, with a particular style that unfolded from work to work. After so many folds - or unfolds - we finally arrive at the fold open to all the freedoms of becoming-creation. Despite the unhingeing effect of the post-war period, his works coexist, interconnecting to each other.

And so we have the Ronchamp Chapel. A strange object, objet à réaction poétique, designed in folds in itself. One sees its exterior, but one sees it as a whole body - as an organ. But the interior body feeds off another body, folded in itself - that which is truly interior. The interior of the interior, cavernous. Like a grotto. To use the terminology of José Gil, there is a seen-known interior and a non-seen-known interior ${ }^{84}$. As if one were looking at a human body inside out, but there is a second reverse side. Ronchamp, in this senses, is truly visceral. It cannot not contain organs because the exterior itself is an

83. Gil, O imperceptível devir da imanência: sobre a filosofia de Deleuze, 193.

84. Ibid, 195. 
organ. An organ in a continuous connection and disconnection with its internal organs. An architectural object as a desiring-machine.

As Gil argues, "the perception of a work of architecture implies the virtual reversion of the interior on the exterior." ${ }^{85}$ In the case of Ronchamp, we witness the doubling down of an interior on the interior - that is the reversion proposed by Le Corbusier. That doubling down is the plane on which the bodies of the visitors - or observers - and the body of the constructed element collide. The plane - or body without organs - is the plane of aesthetic perception. "Thus, the becoming-building of the observer's body marries with the becoming-body of the artistic building." 86 On this plane of intensities new organs in the body without organs are born. But, as Deleuze and Guattari argue, the "[d]esiring-machines work only when they break down, and by continually breaking down." ${ }^{87}$ That is also the role of the body without organs. So what takes place in Le Corbusier's chapel? The body without organs, the plane of architectural aesthetic perception, is potentiated by something very close to the error or the defect. Which is calculated in its openness; expectant. Bravo! We have come close to the living thing.

With this in mind, we go - non-chronologically - from La Tourette to the Chapel of Notre-Dame-du-Haut - a post-desiring-machine? The Chapel is a body: a centrifugal force that takes control of its organs, designing its own interiority in interiority. From non-unity as a whole to machinic unity as an engulfing whole. A part object swallowed by an internal organism. And we are reminded of the seashell's negative imprint in the concrete panel (Figure 5).

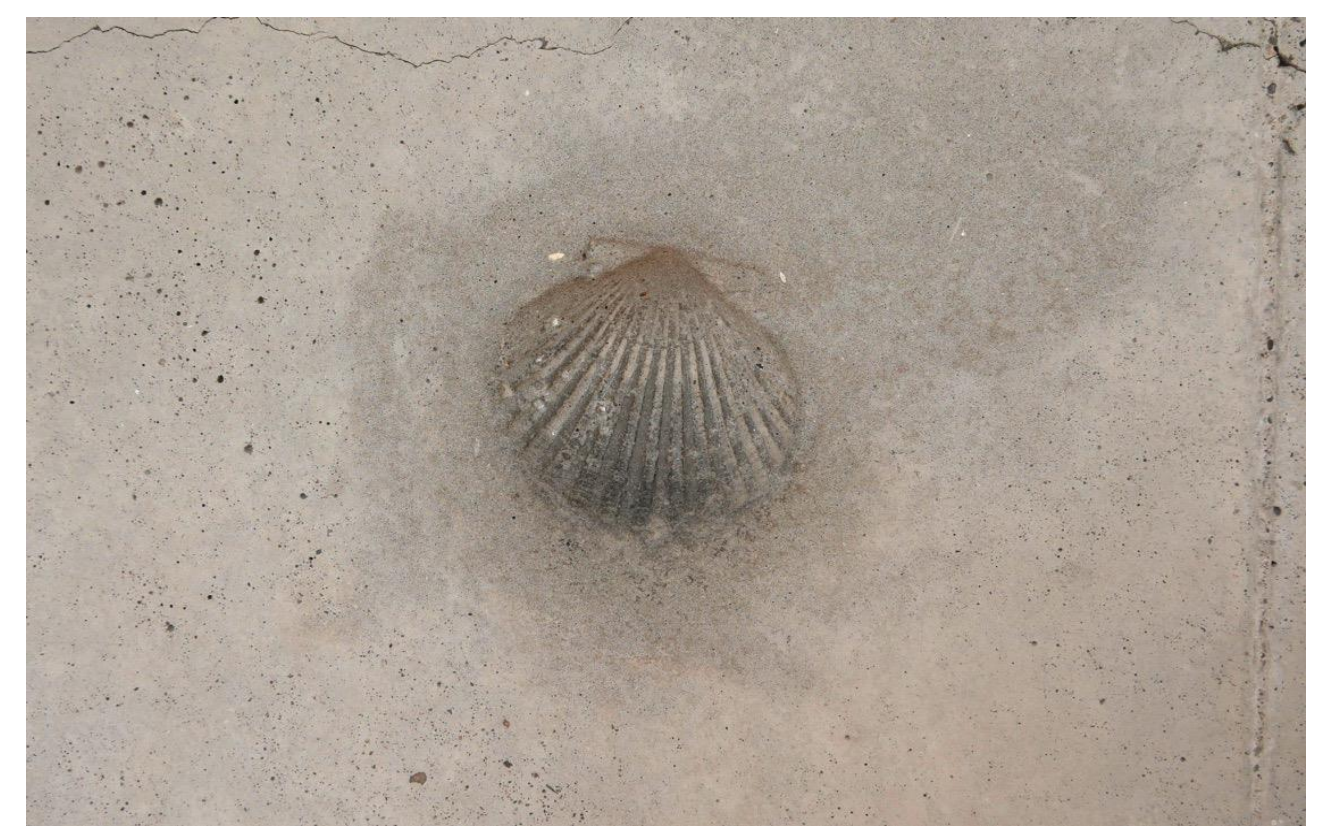

Figure 5. Concrete Door Panel at the Chapelle Notre Dame du Haut Source: Maria João Soares, 2015.

85. Ibid, 194-195.

86. Ibid.

87. Deleuze and Guattari, Anti-Oedipus, 19. 
Let us recall, once again, Valéry em Sea Shells: where does the mollusk end and its shell begin? All as one, as living in a living thing.

\section{Conclusions}

"Our epoch is fixing its own style day by day. It is there under our eyes. Eyes which do not see." 88

This comment from Le Corbusier could be from the present. We still have our eyes closed; one could say, we are even blind. Where are we today? Of what machines would Le Corbusier speak or write today? We cannot forget: "Everything is a machine." 89 To take this further: every machine is a machine connected to another machine. Body, as a machine, connected to architecture, as a machine. "Desiring-machines make us an organism; [...]." ${ }^{\text {"90 }}$ Desiringmachines, make me a home. Make me as a home, living-in-a-living-object, "[...] for a house or a palace is an organism comparable to a living being."

Paths towards a living-in-a-living-object, towards a new architecture.

At the end, Le Corbusier has "given" his body to the sea.

The sea. The end. A new beginning.

\section{Acknowledgments}

This paper is funded by National Funds through FCT - Fundação para a Ciência e a Tecnologia under Project UID/AUR/04026/2013

\section{Bibliography}

Baudelaire, Charles. As flores do mal [The Flowers of Evil.] Lisboa: Assírio e Alvim, 1992.

Benton, Tim. LC Foto: Le Corbusier Secret Photographer. Zurich: Lars Müller, 2013.

Deleuze, Gilles and Felix Guattari. "Balance-Program for Desiring Machines." In Lotus International 123. Milan: Editoriale Lotus, 2005: 60-62.

Deleuze, Gilles and Felix Guattari. Anti-Oedipus. London: Bloomsbury, 2012.

Deleuze, Gilles and Felix Guattari. A Thousand Plateaus. London: Bloomsbury, 2015.

Gil, Jose. O imperceptivel devir da imanência: sobre a filosofia de Deleuze [The Imperceptible Imanence of Becoming: On Deleuze's Philosophy.] Lisboa: Relógio D'Água, 2008.

Le Corbusier and Jean Petit. Textes et dessins pour Ronchamp [Texts and Sketches for Ronchamp.] Genève: Association œuvre de Notre-Dame-du-Haut, 1990.

88. Le Corbusier, Towards a New Architecture, 95.

89. Deleuze and Guattari, Anti-Oedipus, 12.

90. Ibid, 19.

91. Le Corbusier, Towards a New Architecture, 180. 
Le Corbusier. L'Art décoratif d'aujourd'hui [The Decorative Art of Today.] Paris: Flammarion, 1996.

Le Corbusier. "Mise au point." In Le Corbusier: The Final Testament of Père Corbu. By Ivanka Žaknić. New Haven, CT: Yale University Press, 1997: 83-101.

Le Corbusier and Hugues Desalle. "The Final Year: A Transcription of Le Corbusier's Last Recorded Interview." In Le Corbusier: The Final Testament of Père Corbu. By Ivanka Žaknić. New Haven, CT: Yale University Press, 1997: 103-131.

Le Cobusier. Le poème de L'angle droit [The Poem of the Right Angle.] Paris: Editions Connivences, 1989.

Le Corbusier. Modulor 2. Basel: Birkhäuser, 2004.

Le Corbusier. Towards a New Architecture. Mansfield, CT: Martino Publishing, 2014.

Maak, Niklas. Le Corbusier: the Architect on the Beach. Munich: Hirmer, 2011.

Mansoor, Jaleh. "Kurt Schwitters's Merzbau: The Desiring House." In Lotus International 123. Milan: Editoriale Lotus, 2005: 42-59.

Oliver. Mary. "Foreward." In Sea Shells. By Paul Valéry. Boston, MA: Beacon Press, 1995: 5-10.

Wogenscky, Andre. Les mains de Le Corbusier [Le Corbusier's Hands.] Paris: Éditions du Moniteur, 2006.

Valéry, Paul. Eupalinos ou l'Architecte - L'Âme et la danse - Dialogue de l'arbre [Eupalinos: or, The architect.] Paris: Editions Gallimard, 1995.

Valéry, Paul. Sea Shells. Boston, MA: Beacon Press, 1998. 
